Jurnal Keperawatan Silampari

Volume 4, Nomor 1, Desember 2020

e-ISSN: 2581-1975

p-ISSN: 2597-7482

DOI: https://doi.org/10.31539/jks.v4i1.1766

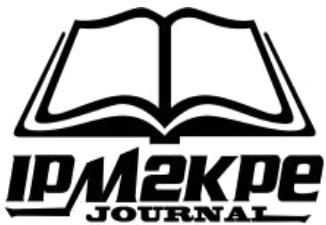

\title{
SIKAP WANITA USIA SUBUR DALAM MELAKUKAN DETEKSI DINI KANKER SERVIKS MELALUI DUKUNGAN SUAMI
}

\author{
Putu Indah Sintya Dewi ${ }^{1}$, Putu Wahyu Sri Juniantari Sandy ${ }^{2}$, \\ Dewa Ayu Carma Krisna Dewi ${ }^{3}$ \\ Sekolah Tinggi Ilmu Kesehatan Buleleng ${ }^{1,2,3}$ \\ indahsintya88@gmail.com ${ }^{1}$
}

\begin{abstract}
ABSTRAK
Penelitian ini bertujuan untuk mengetahui hubungan dukungan suami dengan sikap wanita usia subur dalam melakukan deteksi dini kanker serviks melalui tes IVA di Wilayah Kerja Puskesmas Sawan I. Metode yang digunkan dalam penelitian ini adalah non eksperimen yang mengkaji dengan desain penelitian deskriptif korelasional. Hasil penelitian menunjukkan bahwa nilai $\mathrm{p}$ 0,0001. Simpulan, ada hubungan dukungan suami dengan sikap wanita usia subur dalam melakukan deteksi dini kanker serviks di Wilayah Kerja Pukesmas Sawan I.
\end{abstract}

Kata Kunci: Dukungan Suami, Kanker Serviks, Tes IVA, Wanita Usia Subur

\section{ABSTRACT}

This study aims to determine the relationship between the husband's support and the attitudes of women of childbearing age in the early detection of cervical cancer through the IVA test in the Sawan I Public Health Center. The method used in this research is non-experiment, which studies with correlational descriptive research design. The results showed that the p-value was 0.0001. In conclusion, there is a relationship between the husband's support and the attitudes of women of childbearing age in the early detection of cervical cancer in the Sawan I Community Health Center.

Keywords: Husband's Support, Cervical Cancer, IVA Test, Fertile Age Women

\section{PENDAHULUAN}

Kanker serviks adalah satu dari sekian kanker yang paling menakutkan bagi wanita. Angka harapan hidup yang minim dan mahalnya pengobatan bila terserang, membuat kanker serviks kian terasa mengerikan bagi siapa pun. Mengingat tingkat bahaya dan mahalnya biaya mengatasi derita kanker serviks (Sab'ngatun \& Riawati, 2019).

Kanker serviks disebabkan oleh proses infeksi oleh beberapa tipe Human Papilloma Virus (HPV). Proses ini menyebabkan proliferasi abnormal pada permukaan epidermal dan mukosa serviks (Ocvitanti, 2017). Pada umumnya virus yang paling sering ditemukan pada kasus ini adalah virus tipe 16 dan 18. Bahkan, temuan dalam kasus bisa mencapai di atas $70 \%$ dari semua kasus yang tercatat dalam laporan. Hasil penelitian yang dilakukan oleh Ocvitanti (2017) menyatakan bahwa invensi HPV terjadi diatas $99 \%$ kasus kejadian kanker serviks. Penelitian serupa juga dilaksanakan pada 1000 sampel dari 22 negara (Fauza et al., 2019). 
World Health Organization (WHO) tahun 2010 menyatakan bahwa kanker serviks merupakan kanker terbanyak nomor dua yang diderita oleh perempuan didunia setelah kanker payudara. Ditemukan sekitar 500.000 kasus baru dengan kematian sebanyak 250.000 setiap tahun. Di Indonesia kanker serviks berada pada rangking pertama dan sebagian besar pasien (lebih dari 60\%) pada tahap lanjut. Kondisi penderita pada umumnya berusia produktif, serta ditemukan mulai pada usia 25 tahun dengan rata-rata berusia pada rentang di atas 40 tahun (Astuti \& Kurniati, 2019).

Angka kejadian kanker serviks di Provinsi Bali kejadian tertinggi yaitu sebesar 0,7\% dan kejadian kanker payudara sebesar 0,6\% (Kemenkes RI, 2017). Laporan tahunan RSUD Kabupaten Buleleng kasus kanker serviks yang ditangani pada tahun 2012 yaitu sebanyak 36 penderita dan tahun 2013 terdapat 29 penderita kanker serviks yang telah menjalani perawatan pada bulan Januari sampai bulan Agustus (Dinkes, 2017). Di Bali tahun 2011 berdasarkan data dari Rumah Sakit Umum Pusat Sanglah sebagai rumah. Rumah Sakit Rujukan adalah 150 orang per 100.000 penduduk atau sekitar 5.000 orang. Sementara angka kematian ibu sekitar 82 Orang per 100.000 penduduk. Sebanyak $85 \%$ diantara pengidap kanker serviks meninggal karena stadium lanjut (Dinkes, 2017). Pada tahun 2012 terdapat 460 penderita kanker serviks dirawat, sekitar $85 \%$ diantara penderit kanker serviks meninggal karena sudah pada stadium lanjut (Gustiana et al., 2017).

Program Kementrian Kesehatan RI, deteksi dini kanker serviks yaitu 50\% perempuan berusia 30-50 tahun. Kegitan ini dilaksanakan di puskesmas dengan rujukan ke rumah sakit kabupaten/kota dan rumah sakit tingkat provinsi. Cakupan hasil kegiatan dari tahun 2007 sampai 2014 yaitu telah dilakukan skrining terhadap 9049.099 orang $(2,45 \%)$. Hasil IVA positif sebanyak 44.654 orang $(4,94 \%)$ suspek kanker serviks sebanyak 1.056 orang (1,2 per 1000 orang) (Kemenkes RI, 2017).

Kurang lebih $75 \%$ sampai $87 \%$ dari pengetahuan manusia diperoleh melalui mata. Kurang lebih $13 \%$ sampai $25 \%$ dari pengetahuan diperoleh melalui indera lain informasi merupakan kondisi pertama untuk suatu sikap. Adapun dukungan suami berupa motivasi, dorongan, informasi, empati, ataupun bantuan yang dapat membuat individu lainnya merasa lebih tenang dan aman. Dukungan suami dapat mendatangkan rasa senang, rasa aman, rasa puas, rasa nyaman dan membuat individu yang bersangkutan mendapatkan dukungan emosional yang dapat mempengaruhi kesejahteraan jiwa manusia (Yustisianti, 2017).

Seorang istri yang dominan bersikap positif terhadap tes IVA lebih besar kemungkinan memutuskan melakukan tes IVA. Terbentuknya sikap istri dalam upaya deteksi dini kanker leher Rahim dengan tes IVA disebabkan terdapat berbagai faktor yang mempengaruhi pembentukan sikap (Andarwati et al., 2020; Ayuningtiyas \& Ropitasari, 2018).

Berdasarkan Studi Pendahuluan yang dilakukan peneliti pada tanggal 15 Maret 2019 di Puskesmas Sawan 1 di peroleh data jumlah kunjungan tes IVA pada bulan Januari 2018 sampai Januari 2019 sebanyak 388 orang perempuan. Selama studi pendahuluan peneliti melakukan wawancara dengan pengunjung puskesmas yang berjumlah 8 orang perempuan, dimana 5 orang perempuan rutin melakukan tes IVA karena adanya dukungan dari keluarga dan 3 orang perempuan tidak rutin melakukan tes IVA karena tidak ada dukungan dari keluarga.

Beberapa penelitian terdahulu hanya mengkaji dari sisi seorang istri saja dalam menyikapi hasil tes IV A atau kankers serviks, namun dalam penelitian ini, penulis juga mengkaji sisi dukungan suami dalam mendapatkan pengetahuan dan informasi 
kesehatan reproduksi yang baik tentang tes IVA sebagai deteksi dini kanker leher rahim dan tidak ada rasa takut dan malu dalam melakukan tes IVA untuk istrinya.

\section{METODE PENELITIAN}

Penelitian ini menggunakan desain penelitian deskriptif korelasional yang mengkaji hubungan antar variabel, yaitu untuk mengetahui hubungan dukungan suami dengan sikap wanita usia subur dalam melakukan deteksi dini kanker serviks. Pada penelitian deskriptif korelasional ini menggunakan rancangan penelitian croos sectional, dimana pengukuran/observasi data variabel bebas dan variabel terikat hanya satu kali pada satu saat.

Populasi yang digunakan sebagai subyek dalam penelitian ini adalah wanita usia subur dalam melakukan deteksi dini kanker serviks melalu tes IVA di Puskesmas Sawan I, sebanyak 380 orang. Jadi, besar sampel yang digunakan berjumlah 195 orang. Penelitian ini menggunakan Nonprobability sampling jenis purposive sampling.

Uji analisis yang di gunakan dalam penelitian ini adalah untuk mengetahui adanya hubungan variabel bebas dengan variabel terikat. Uji hipotesis menggunakan uji korelasi Spearman Rank. Proses analisa menggunakan program computer dengan tingkat kpercayaan 95\% atau tingkat kesalahan 5\% (0,05), jika nilai $\mathrm{p}<\alpha$ sebesar 0.05 maka H0 ditolak, yang berarti terdapat hubungan dukungan suami dengan sikap wanita usia subur dalam melakukan deteksi dini kanker serviks dengan metode tes IVA .

\section{HASIL PENELITIAN}

Analisa Univariat

Tabel. 1

Distribusi Responden

Berdasarkan Usia

\begin{tabular}{|c|c|c|c|c|}
\hline & $\mathrm{N}$ & Mean & Minimum & Maksimum \\
\hline Usia & 195 & 38,31 & 30 & 50 \\
\hline
\end{tabular}

Berdasarkan tabel 1 menunjukkan bahwa rata-rata usia wanita usia subur yaitu 38,31 standar devisi 5,488.

Tabel. 2

Distribusi Responden Berdasarkan

Tingkat Pendidikan

\begin{tabular}{ccc}
\hline Tingkat Pendidikan & Frekuensi (f) & Persentase (\%) \\
\hline Tidak Sekolah & 0 & 0,0 \\
SD & 47 & 24,1 \\
SMP & 59 & 30,3 \\
SMA & 79 & 40,5 \\
Sarjana & 10 & 5,1 \\
\hline Total & 195 & 100
\end{tabular}

Berdasarkan tabel 2 menunjukkan bahwa mayoritas responden berada pada tingkat Pendidikan SMA yaitu 79 orang (40,5\%). 
Tabel. 3

Distribusi Responden

Berdasarkan Pekerjaan

\begin{tabular}{ccc}
\hline Pekerjaan & Frekuensi (f) & Persentase (\%) \\
\hline Bekerja & 63 & 32,3 \\
Tidak Bekerja & 132 & 67,7 \\
\hline Total & 195 & 100
\end{tabular}

Dari hasil tabel 3 menunjukkan bahwa sebagian besar responden tidak bekerja yaitu 132 orang $(67,7 \%)$.

Tabel. 4

Distribusi Responden

Dukungan Suami

\begin{tabular}{ccc}
\hline Kategori & Frekuensi (f) & Persentase (\%) \\
\hline Rendah & 56 & 28,7 \\
Cukup & 71 & 36,4 \\
Tinggi & 68 & 34,9 \\
\hline Total & 195 & 100 \\
\hline
\end{tabular}

Berdasarkan tabel 4 menunjukkan bahwa sebagaian besar dukungan suami berada dalam kategori cukup 71 orang $(36,4 \%)$.

Tabel. 5

Distribusi Responden

Sikap Wanita Usia Subur

\begin{tabular}{ccc}
\hline Kategori & Frekuensi (f) & Persentase(\%) \\
\hline Sikap Negatif & 96 & 49,2 \\
Sikap Positif & 99 & 50,8 \\
\hline Total & 195 & 100 \\
\hline
\end{tabular}

Berdasarkan tabel 5 menunjukkan bahwa sebagian besar sikap wanita usia subur berada dalam kategori sikap positif sebanyak 99 orang (50,8\%).

\section{Analisis Bivariat}

Tabel. 6

Tabulasi Hubungan Dukungan Suami dengan Sikap Wanita Usia Subur dalam Melakukan Deteksi Dini Kanker Serviks Melalui Tes IVA

\begin{tabular}{lccccc}
\hline \multirow{2}{*}{$\begin{array}{c}\text { Sikap Wanita } \\
\text { Usia Subur }\end{array}$} & \multicolumn{3}{c}{ Dukungan Suami } & \multirow{2}{*}{ Total } & $\begin{array}{c}\text { P- } \\
\text { Value }\end{array}$ \\
\cline { 2 - 4 } & Rendah & Cukup & Tinggi & & \\
\hline Sikap Negatif & $45(23,1 \%)$ & $47(24,1 \%)$ & $4(2,1 \%)$ & $96(49,2 \%)$ & 0,000 \\
Sikap Positif & $11(5,6 \%)$ & $24(12,3 \%)$ & $64(32,8 \%)$ & $99(50,8 \%)$ & \\
\hline Total & $56(28,7 \%)$ & $71(36,4 \%)$ & $68(34,9 \%)$ & $195(100,0 \%)$ & \\
\hline
\end{tabular}


Berdasarkan tabel 6 menunjukkan bahwa sebagian besar respoden memiliki dukungan suami yang cukup sebanyak 71 orang $(36,4 \%)$, dengan sikap yang positif.

Tabel. 7

Analisis Hubungan Dukungan Suami dengan Sikap Wanita Usia Subur dalam Melakukan Deteksi Dini Kanker Serviks Melalui Tes IVA

\begin{tabular}{llc}
\hline \multicolumn{2}{c}{ Uji Korelasi Rank Spearman } \\
\hline \multicolumn{2}{c}{ Dukungan Keluarga } \\
\hline Sikap Wanita Usia Subur & Correlation Coefficient & 0,531 \\
& Sig. & 0,000 \\
\cline { 2 - 3 } & $\mathrm{N}$ & 195 \\
\hline
\end{tabular}

Berdasarkan tabel 7 menunjukan nilai $\mathrm{r}=0,531 P$ value 0,000 dan dari hasil tersebut $p$-value $\leq 0,05$, dengan tingkat hubungan sedang dan arah yang positif yang artinya semakin tinggi dukungan suami yang diberikan maka semakin positif sikap wanita usia subur.

\section{PEMBAHASAN}

Dilihat dari karakteristik responden yang merupakan wanita usia subur yang berada di Wilayah Puskesmas Sawan I, sebagian besar responden berpendidikan SMA. Berdasarkan pekerjaan sebagian besar responden tidak bekerja dan sebagian besar dukungan suami berada pada kategori cukup. Menurut asumsi peneliti dukungan suami akan sangat memberikan dampak pada sikap wanita dan mayoritas dukungan suami yang diberikan cukup. Sebagai seorang kepala dalam keluarga, suami merupakan orang terdekat bagi seorang istri.

Dukungan suami menjadi faktor yang penting dalam menentukan sikap istri. Hal ini karena dukungan dari suami dijadikan sebagai dasar dalam menentukan keputusan yang diambil oleh istri. Dukungan ini penting juga sebagai upaya preventif serta promotif terhadap peningkatan derajat kesehatan. Hasil penelitian ini sejalan dengan hasil penelitian sebelumnya yang dilakukan oleh Wulandari et al., (2018) didapatkan hasil dukungan suami sedang yaitu 35 responden $(57,4 \%)$, rendah 17 responden $(27,9 \%)$, dan tinggi 9 responden $(14,8 \%)$.

Berdasarkan hasil penelitian yang di lakukan didapatkan hasil sebagian besar sikap wanita usia subur berada pada kategori sikap negative. Menurut asumsi peneliti sikap negative pada wanita usia subur disebabkan karena kurangnya motivasi, dukungan dan kurangnya informasi pada dirinya. Sikap belum merupakan tindakan atau aktivitas, akan tetapi merupakan suatu predisposisi perilaku. Sejalan dengan penelitian yang dilakukan oleh Yuliani et al., (2020) didapatkan bahwa dari 195 responden dengan sikap negatif sebanyak 106 orang $(54,4 \%)$, dan sikap positif sebanyak 89 orang $(45,6 \%)$.

Berdasarkan hasil uji statistic Spearman Rank menunjukan bahwa ada Hubungan yang signifikan antara dukungan suami dengan sikap wanita usia subur khususnya dalam melakukan deteksi dini kanker serviks metode IVA di Wilayah Puskesmas Sawan I.

Dukungan suami merupakan faktor yang paling dominan mempengaruhi partisipasi wanita usia subur dalam deteksi dini kanker serviks dibandingkan dengan pengetahuan, sikap dan akses informasi oleh wanita usia subur (Ayuningtiyas, 2018). Dukungan yang kuat dari orang terdekat termasuk suami cenderung akan membuat 
responden termotivasi. Peran suami sangat kuat dalam memberikan dukungan bagi wanita untuk melakukan pemeriksaan kesehatan. Selain sebagai penyedia dana, suami juga berperan dalam pengambilan keputusan kemana harus mencari pertolongan dan pengobatan kesehatan (Wulandari et al., 2018).

Suami dan keluarga merupakan orang terdekat dengan wanita usia subur untuk bertukar pikiran dan informasi. Sikap pandangan serta reaksi yang berbeda-beda tergantung individu yang bersangkutan terhadap situasi yang terjadi. Wujud nyata sikap yang ditunjukkan seseorang secara implisit tanpa bisa kita rasakan secara objektif. Hal ini tentunya disesuaikan dengan keragaman rangsangan dalam kehidupan sehari-hari. Inilah yang bersifat emosional tergantung dari stimulus saat berinteraksi sosial (Astuti \& Kurniati, 2019). Sikap juga merupakan predisposisi terhadap suatu tindakan (Afni \& Rasyid, 2017).

Didukung dengan penelitian yang dilakukan oleh Yustisianti (2017) didapatkan hasil penelitian WUS yang memiliki dukungan rendah dari suami dengan perilaku positif dalam melakukan pemeriksaan IVA. Data tersebut menunjukkan bahwa dukungan suami mempengaruhi perilaku WUS melakukan pemeriksaan IVA. Penelitian terkait lainnya adalah sejalan dengan penelitian yang dilakukan oleh (Wulandari et al., 2018) didapatkan hasil sebagian besar suami mendukung perilaku pemeriksaan IVA test yaitu sebanyak 48 orang $(68,57 \%)$. Sebagian besar perilaku pemeriksaan IVA test pada ibu tidak teratur yaitu sebanyak 40 orang $(57,14 \%)$. Hasil uji chi square antara dukungan suami dengan perilaku pemeriksaan metode IVA test didapat nilai signifikansi 0,021 (<0,005). Sedangkan dalam penelitian (Budiman et al., 2019) menyebutkan bahwa wanita usia subur (WUS) yang melakukan pemeriksaan IVA tes, tahun 2010 yang melakukan IVA tes sebanyak 60,5\%, terus menunjukkan penurunan sampai tahun 2013 menjadi 23,7\%, kemudian naik kembali menjadi 43,6\% pada tahun 2015, dan pada tahun 2016 turun lagi menjadi 41,0\%.

Sedangkan dalam penelitian Yuliani et al., (2020) Angka kejadian kanker serviks di Indonesia cukup tinggi karena kurangnya pengetahuan wanita tentang kanker leher rahim dan IVA test masih rendah, sehingga sebagian besar wanita tidak melakukan IVA test. IVA (Inpeksi Visual Asamasetat) adalah pemeriksaan leher rahim (serviks) dengan cara melihat langsung (dengan mata telanjang) leher rahim setelah memulas leher rahim dengan larutan asam asetat 3\% - 5\%. Peserta pemeriksaan IVA berusia lebih dari 40 tahun, mayoritas memiliki 2 anak, sebagian besar berpendidikan menengah dan usia menikah pada kurun waktu reproduksi sehat yaitu usia antara 20 hingga 35 tahun. Hasil pemeriksaan IVA menunjukkan semua peserta pemeriksaan IVA tidak ada yang mengalami gejala yang mencurigakan ke arah kanker serviks, artinya IVA tes dalam kategori negatif, didapatkan $15 \%$ peserta mengalami erosio portionis uteri dan $85 \%$ dalam kondisi sehat serviks.

\section{SIMPULAN}

Ada hubungan dukungan suami dengan sikap wanita usia subur dalam melakukan deteksi dini kanker serviks melalui tes IVA di Wilayah Puskesmas Sawan I, semakin tinggi dukungan keluarga yang diberikan maka sikap wanita usia subur akan positif.

\section{SARAN}

Bagi institusi pendidikan diharapkan dapat memberikan pengetahuan kepada keluarga dan pasien yang melakukan deteksi dini kanker serviks melalui tes IVA. Bagi tempat penelitian diharapkan menjadi referensi bagi mahasiswa keperawatan dan 
menjadi data awal untuk melakukan penelitian lanjutan, seperti hubungan dukungan suami dengan sikap wanita usia subur dalam melakukan deteksi dini kanker serviks melalui tes IVA Di Puskesmas Sawan I.

Bagi masyarakat diharapkan dapat memberikan pengetahuan terhadap masyarakat tentang deteksi dini kanker serviks melalui tes IVA. Bagi peneliti selanjutnya diharapkan dapat meningkatkan wawasan dan kemampuan peneliti dalam melakukan penelitian sesuai kaidah yang berlaku, penelitian ini diharapkan bisa menjadi acuan penelitian selanjutnya.

\section{DAFTAR PUSTAKA}

Afni, N., \& Rasyid, N. (2017). Faktor-Faktor yang Berhubungan dengan Perilaku WUS (Wanita Usia Subur) tentang Deteksi Dini Kanker Leher Rahim Metode IVA (Inspeksi Visual Asam Asetat) di Puskesmas Singgani. Promotif, 7(1), 63-75. DOI: 10.31934/promotif.v7i1.26

Andarwati, D, Indriani, I., \& Sulistyaningsih, S. (2020). Deteksi Dini Kanker Serviks pada Wanita Usia Subur. Jurnal Keperawatan, 12(2), 301-306. DOI: https://doi.org/https://doi.org/10.32583/keperawatan.v12i2.776

Astuti, D. A., \& Kurniati, N. (2019). Deteksi Dini Kanker Serviks dengan IVA Test pada Kelompok Rentan Terkena HIV. Jurnal Surya Masyarakat, 1(2), 111-115. DOI: $10.26714 /$ jsm.1.2.2019.111-115

Ayuningtiyas, I. (2018). Hubungan antara Dukungan Suami dengan Sikap Istri Tes IVA di Puskesmas Jaten Kabupaten Karanganyar. Placentum: Jurnal Ilmiah Kesehatan dan Aplikasinya 6 (2), 33-40. DOI: 10.20961/placentum.v6i2.22854

Budiman, B., Hidayat, Y. M., \& Harsono, A. B. (2019). Evaluasi Program Deteksi Dini Kanker Serviks dengan Metode See And Treat di Kabupaten Karawang. Indonesian Journal of Obstetrics \& Gynecology Science, 2(1), 72-80. DOI: 10.24198/obgynia.v2n1.77

Dinkes. (2017). Profil Kesehatan Buleleng. Profil Kesehatan Kabupaten BULELENG, 38-74

Fauza, M., Aprianti, A., Azrimaidalisa, A. (2019). Faktor yang Berhubungan dengan Deteksi Dini Kanker Serviks Metode IVA di Puskesmas Kota Padang, Jurnal Promosi Kesehatan Indonesia, 14(1), 68-80. DOI: https://doi.org/10.14710/jpki.14.1.68-80

Gustiana, D., Dewi, Y. I., \& Nurchayati, S. (2017). Faktor-Faktor yang Berhubungan dengan Perilaku Pencegahan Kanker Serviks pada Wanita Usia Subur. Jurnal Online Mahasiswa, 1(2), 1-8. https://jom.unri.ac.id/index.php/JOMPSIK/article/view/3432

Kemenkes RI. (2017). Analisis Lansia di Indonesia. Pusat Data dan Informasi. www.depkes.go.id/download.php?file $=$ download/.../infodatin lansia 2016.pdf\%0A

Ocvitanti, D. (2017). Tes Pap, Tes HPV dan Servikografi sebagai Pemeriksaan Triase untuk Tes IVA Positif: Upaya Tindak Lanjut Deteksi Dini Kanker Serviks pada Fasilitas Kesehatan dengan Sumber Daya Terbatas Beserta Analisis Sederhana Efektivitas Biayanya. INAJOG: Indonesian Journal of Obstetric and Gynecology, 31(4), 201-211. http://www.inajog.com/index.php/journal/article/view/134/127

Sab'ngatun, S., \& Riawati, D. (2019). Hubungan Antara Usia dengan Deteksi Dini Kanker Serviks Metode IVA. Avicenna: Journal of Health Researh, 2(2), 104110. DOI: https://doi.org/10.36419/avicenna.v2i2.306 
Wulandari, N., Astuti, T., \& Fadhilah, S. (2018). Hubungan Dukungan Suami dengan Perilaku Pemeriksaan Inspeksi Visual Asetat (IVA) Test di Wilayah Kerja Puskesmas Cangkringan Sleman Yogyakarta. Jurnal Kesehatan Karya Husada, 7(1), 57-65. http://jurnal.akeskhjogja.ac.id/index.php/jkkh/article/view/257

Yuliani, I., Lusia, B. A., \& Widiati, E. N. (2020). Deteksi Dini Kanker Leher Rahim (Kanker Serviks) dengan Metode IVA, 3(2), 8-14. http://dharmabakti.respati.ac.id/index.php/dharmabakti/article/view/117

Yustisianti, E. N. (2017). Hubungan Dukungan Suami dengan Perilaku Wanita Usia Subur (WUS) Melakukan Pemeriksaan Inspeksi Visual Asam Asetat (IVA) di Puskesmas Kasihan I. Naskah Publikasi. http://digilib.unisayogya.ac.id/2998/ 